\title{
TINGKAT PENGUASAAN GURU SEKOLAH DASAR DALAM MENGIMPLEMENTASIKAN PENDEKATAN SAINTIFIK
}

\section{Ronald Fransyaigu, Bunga Mulyahati}

\author{
Universitas Samudra
}

\section{Sejarah Artikel}

Diterima 30 November 2017

Disetujui 25 Juli 2018

Diterbitkan 1 Agustus 2018

\section{Kata Kunci}

profil guru, sekolah dasar, pendekatan saintifik

\begin{abstract}
Abstrak
Pendekatan saintifik/ilmiah merupakan proses pembelajaran yang menggunakan proses berpikir ilmiah. Pendekatan ilmiah dapat dijadikan sebagai jembatan untuk perkembangan dan pengembangan sikap, keterampilan dan pengetahuan peserta didik. Para ahli yang meyakini bahwa melalui pendekatan saintifik/ilmiah, selain dapat menjadikan peserta didik lebih aktif dalam mengkonstruksi pengetahuan dan keterampilannya, juga dapat mendorong peserta didik untuk melakukan penyelidikan guna menemukan fakta-fakta dari suatu fenomena atau kejadian. Penelitian ini dilakukan untuk menganalisis kebutuhan secara lebih jelas dan mengetahui secara lebih mendalam mengenai profil kemampuan guru sekolah dasar dalam mengimplementasikan pendekatan saintifik, sehingga dapat dijadikan acuan untuk melakukan pembinaan guru sekolah dasar dalam meningkatkan mutu pembelajaran.Penelitian ini menggunakan metode survey untuk mendapatkan data dari Sekolah Dasar se-Kota Langsa yang alamiah (bukan buatan) tetapi peneliti melakukan perlakuan dalam pengumpulan pengumpulan data dengan cara mengedarkan kuesioner dan wawancara terstruktur. Penerapan metode statistik untuk mengumpulkan, mengolah dan menyajikan data serta tenik menganalisis data kuantitatif dilakukan secara deskriptif dengan tidak bermaksud membuat generalisasi. Hasil penelitian mengungkapkan bahwa guru-guru di dua SD ini sudah menunjukkan pemahaman yang baik tentang pendekatan saintifik. Pada proses pembelajaran langkah mengamati, menanya, mengumpulkan informasi, mengasosiasi, sampai mengkomunikasikan sudah muncul dalam proses pembelajaran meskipun tidak secara berurutan.
\end{abstract}

\section{Cara Mengutip}

Fransyaigu, R., Mulhayati, B. (2018). Tingkat Penguasaan Guru Sekolah Dasar dalam Mengimplementasikan Pendekatan Saintifik. DWIJA CENDEKIA: Jurnal Riset Pedagogik, 2 (1), 5260 


\section{PENDAHULUAN}

Pembelajaran merupakan suatu kegiatan yang kompleks. Pembelajaran pada hakekatnya tidak hanya sekedar menyampaikan pesan pembelajaran kepada siswa, akan tetapi merupakan aktifitas profesional yang menuntut guru untuk dapat menggunakan keterampilan dasar mengajar secara terpadu, serta menciptakan situasi dan kondisi yang memungkinkan siswa dapat belajar secara efektif dan efisien. Oleh karena itu dalam pembelajaran guru perlu menciptakan suasana yang kondusif dan strategi belajar yang menarik minat siswa.

Upaya perbaikan proses pembelajaran terus dilakukan oleh lembaga pendidikan, pada dasarnya mengarah ke pembelajaran yang berkualitas. Pembelajaran yang dapat mengembangkan kemampuan berpikir dan menekankan keterlibatan siswa secara aktif (student centered). Iklim pembelajaran yang berkualitas dapat dicapai jika pembelajaran tersebut menarik, menantang, menyenangkan dan bermakna bagi siswa (Tim Pengembang PKP, 2006).

$$
\text { Kenyataan di lapangan }
$$

menunjukkan bahwa sistem

pendidikan lebih menekankan pada penyampaian informasi dari pada pengembangan kemampuan berpikir (Zubaidah, 2010). Aswandi (2009) menambah- kan bahwa sampai saat ini pembelajaran masih kental berpusat pada guru (teacher centered) dimana gaya belajar setiap siswa mengikuti gaya mengajar guru. Wartono (2006) juga menyatakan bahwa kenyataan menunjukkan kadar inkuiri yang ada dalam prosespembelajaran di SD saat ini masih sangat rendah. Di lembaga pendidikan pada jenjang Sekolah Dasar dan Menengah, guru kurang memperhatikan aspek kemampuan berpikir dalam proses pembelajaran (Jufri, 2009).

Permendikbud nomor 65 tentang Standar Proses Pendidikan Dasar dan Menengah telah mengisyaratkan tentang perlunya proses pembelajaran yang dipandu dengan kaidah-kaidah pendekatan saintifik/ilmiah.

Pendekatan saintifik/ilmiah merupakan proses pembelajaran yang menggunakan proses berpikir ilmiah. Pendekatan ilmiah dapat dijadikan sebagai jembatan untuk perkembangan dan pengembangan sikap, keterampilan dan pengetahuan peserta didik. Sesuai materi Kemendikbud, dinyatakan bahwa dalam pendekatan atau proses kerja yang memenuhi kriteria ilmiah, para ilmuan lebih mengedepankan pendekatan induktif (inductive reasoning) daripada pendekatan deduktif (deductive reasoning). Penalaran deduktif melihat fenomena umum untuk menarik simpulan yang spesifik. Sebaliknya, penalaran induktif memandang fenomena atau situasi spesifik untuk menarik simpulan secara keseluruhan. Penalaran induktif menempatkan bukti-bukti spesifik ke dalam relasi idea yang lebih luas.

Pendekatan ilmiah merujuk pada teknik-teknik investigasi terhadap suatu atau beberapa fenomena atau gejala, memperoleh pengetahuan baru atau mengoreksi dan memadukan pengetahuan sebelumnya. Pendekatan ini juga 
memanfaatkan metode pencarian (inquiry methods) yang berbasis pada bukti-bukti dari objek yang dapat diobservasi, empiris, dan terukur dengan prinsip-prinsip penalaran yang spesifik. Oleh karena itu, metode ilmiah memuat serangkaian aktivitas pengumpulan data melalui observasi atau eksperiman, mengolah informasi atau data, menganalisis, kemudian memformulasi, dan menguji hipotesis.

Banyak para ahli yang meyakini bahwa melalui pendekatan saintifik/ilmiah, selain dapat menjadikan peserta didik lebih aktif dalam mengkonstruksi pengetahuan dan keterampilannya, juga dapat mendorong peserta didik untuk melakukan penyelidikan guna menemukan fakta-fakta dari suatu fenomena atau kejadian (Sudrajat, 2013). Peserta didik dilatih untuk mampu berpikir logis, runut, dan sistematis.

Berdasarkan uraian tersebut, dapat ditarik simpulan awal bahwa pembelajaran berbasis pendekatan saintifik/ilmiah lebih efektif hasilnya dibandingan dengan pembelajaran tradisional. Pada pembelajaran berbasis pendekatan saintifik/ilmiah, retensi informasi dari guru lebih besar. Penelitian ini dilakukan untuk menganalisis kebutuhan secara lebih jelas dan mengetahui secara lebih mendalam mengenai profil kemampuan guru sekolah dasar dalam pendekatan pembelajaran mengimplementasikan saintifik dalam

\section{METODE PENELITIAN}

Hasil penelitian ini diperoleh Penelitian ini menggunakan metode survey untuk mendapatkan data dari tempat tertentu yang alamiah (bukan buatan) tetapi peneliti melakukan perlakuan dalam pengumpulan pengumpulan data dengan cara melakukan obeservasi dan wawancara terstruktur.

Sampel penelitian adalah 10 sekolah dasar, dengan menggunakan teknik simple random sampling.

Lokasi penelitian ini dilaksanakan di SD Negeri se-Kota

\section{PEMBAHASAN}

Hasil dan pembahasan penelitian ini diperoleh melalui observasi, maupun angket/kuesioner mengenai analisis implementasi pendekatan saintifik di Sekolah Dasar terhadap orang guruguru di SDN Kota Langsa, dari hasil dapat diperoleh gambaran bahwa Pada intinya pendekatan saintifik diterjemahkan guru sebagai sebuah proses pembelajaran yang secara keseluruhan bersifat ilmiah, dimana siswa pada pendekatan saintifik diarahkan untuk berpikir logis, sistematis dalam mencari kesimpulan terhadap materi pembelajaran.
Dengan pendekatan saintifik siswa mengamati secara langsung, memunculkan pertanyaan-pertanyaan dari dan untuk dirinya, mencari informasi dan menganalisis hingga membuat kesimpulan dan mengkomunikasikannya.

Penelitian ini menggunakan Sekolah Dasar yang berlokasi di Kota Langsa yang berjumlah 10 Sekolah Dasar yang terdaftar pada Dinas Pendidikan Kota Langsa tahun 2016 sebagai sample penelitian. Data yang diambil dalam penelitian ini adalah tingkat penguasaan implementasi 
pendekatan saintifik guru sekolah dasar di Kota Langsa.

Analisis statistik deskriptif dilakukan

gambaran atau deskripsi data yang dengan tujuan untuk memberikan

digunakan dalam penelitian.

Tabel 1. Persentase Kemampuan Guru

\begin{tabular}{ccc}
\hline KODE GURU & TOTAL & Persentase (\%) \\
\hline A1 & 34 & 70,83 \\
A2 & 35 & 72,92 \\
B1 & 35 & 72,92 \\
B2 & 34 & 70,83 \\
C1 & 35 & 72,92 \\
C2 & 37 & 77,08 \\
D1 & 34 & 70,83 \\
D2 & 34 & 70,83 \\
E1 & 35 & 72,92 \\
E2 & 32 & 66,67 \\
F1 & 35 & 72,92 \\
F2 & 35 & 72,92 \\
G1 & 34 & 70,83 \\
G2 & 35 & 72,92 \\
H1 & 35 & 72,92 \\
H2 & 34 & 70,83 \\
I1 & 35 & 72,92 \\
I2 & 35 & 72,92 \\
J1 & 35 & 72,92 \\
J2 & 35 & 72,92 \\
\hline
\end{tabular}

Sumber: Hasil Pengolahan data dengan M. Excell

Penjelasan dari tabel 1 dapat diketahui bahwa dari 20 guru sekolah dasar di Kota Langsa yang dijadikan sampel dalam penelitian ini, tingkat penguasaan guru dalam implementasi pendekatan saintifik selama proses pembelajaran di sekolah dasar menunjukan satu orang guru mendapat persentase $66,67 \%$, enam orang guru $70,83 \%, 12$ orang guru $72,92 \%$ dan satu orang guru $77,08 \%$ secara keseluruhan persentase tersebut berada dalam kategori cukup.
Kelemahan-kelemahan pada isian angket yang diberikan kepada guru terlihat pada langkah bertanya baik pertanyaan dari guru atau pun siswa. Keterampilan bertanya tergolong lemah karena proses pembiasaan yang kurang terlihat dari persentase yang rendah diantara nomor isian angket yang lain yakni $66,25 \%$ dan $67,5 \%$. Serta pada tahap refleksi yang melibatkan peserta didik menunjukan angka persentase yang rendah yakni $63,75 \%$. 
Kelemahan yang terjadi dari proses implementasi pendekatan saintifik, dimana pendekatan tersebut merupakan pendekatan yang diusung oleh kurikulum 2013 terjadi karena implementasi kurikulum 2013 khususnya di Kota Langsa hanya terlihat pada covernya saja tapi konten dan rasanya masih berada di kurikulum 2006 (Kurikulum Tingkat Satuan Pendidikan). Hal tersebut yang menjadikan tidak optimalnya pengimplementasian pendekatan saintifik dalam proses pembelajaran.

Tabel 2. Hasil Indentifikasi Etnoliterasi Budaya Desa

\begin{tabular}{lcc}
\hline JUMLAH KESELURUHAN & 693 & 1443,75 \\
\hline NILAI TERTINGGI & 37 & 77,08 \\
NILAI TERENDAH & 32 & 66,67 \\
RATA NILAI & 34,65 & 72,19 \\
\hline
\end{tabular}

Secara keseluruhan pada tabel 2 dapat dilihat tingkat penguasaan implementasi pendekatan saintifik oleh guru sekolah dasar di Kota Langsa memiliki nilai tertinggi 37 dengan persentase $77,08 \%$ dan nilai terendah 32 dengan persentase $66,67 \%$ serta rata-rata 34,65 dengan persentase $72,19 \%$. Dengan demikian tingkat penguasaan dan rata-rata penguasaan guru sekolah dasar dalam implemestasi pendekatan saintifik berada pada kategori cukup.

Berdasarkan pendapat secara umum dari guru di atas, dan untuk menjawab pertanyaan penelitian tentang pemahaman guru tentang implementasi pendekatan saintifik dalam pembelajaran, peneliti akan paparkan kembali tentang kajian pustaka mengenai pengertian pendekatan saintifik. Pendekatan saintifik merupakan pendekatan yang mengadopsi langkah-langkah saintis dalam membangun pengetahuan melalui metode ilmiah. Untuk mengembangkan langkah-langkah saintis dalam membangun pengetahuan, pendekatan pembelajaran yang diperlukan adalah yang memungkinkan terbudayakannya kecakapan berpikir sains, terkembangkannya "sense of inquiry" dan kemampuan berpikir kreatif siswa (De Vito, 1989). Selain itu juga dibutuhkan pendekatan pembelajaran yang mampu menghasilkan kemampuan untuk belajar (Joyce and Weil: 2009), bukan saja diperolehnya sejumlah pengetahuan, keterampilan, dan sikap, tetapi yang lebih penting adalah bagaimana pengetahuan, keterampilan, dan sikap itu diperoleh siswa (Zamroni, 2000).

Pendekatan saintifik tidak hanya memandang hasil belajar sebagai muara akhir, namum proses pembelajaran dipandang sangat penting. Oleh karena itu pendekatan saintifik menekankan pada keterampilan proses. Pendekatan saintifik yang mengacu pada pendekatan pembelajaran berbasis peningkatan keterampilan proses sains adalah model pembelajaran yang mengintegrasikan keterampilan proses sains ke dalam sistem penyajian materi secara terpadu (Rustaman, 2003). Pendekatan ini menekankan pada proses pencarian pengetahuan dari pada transfer pengetahuan, siswa dipandang sebagai subjek belajar yang perlu 
dilibatkan secara aktif dalam proses pembelajaran, guru hanyalah seorang fasilitator yang membimbing dan mengkoordinasikan kegiatan belajar. Dalam pendekatan ini siswa diajak untuk melakukan proses pencarian pengetahuan berkenaan dengan materi pelajaran melalui berbagai aktivitas proses sains sebagaimana dilakukan oleh para ilmuwan (scientist) dalam melakukan penyelidikan ilmiah, dengan demikian siswa diarahkan untuk menemukan sendiri berbagai fakta, membangun konsep, dan nilai-nilai baru yang diperlukan untuk kehidupannya (Rustaman, 2007). Fokus proses pembelajaran diarahkan pada pengembangan keterampilan siswa dalam memproseskan pengetahuan, menemukan dan mengembangkan sendiri fakta, konsep, dan nilai-nilai yang diperlukan (Semiawan: 1992).

Pendekatan ini juga tercakup penemuan makna (meanings), organisasi, dan struktur dari ide atau gagasan, sehingga secara bertahap siswa belajar bagaimana mengorganisasikan dan melakukan penelitian. Pendekatan saintifik menekankan pada kemampuan siswa dalam menemukan sendiri (discover) pengetahuan yang didasarkan atas pengalaman belajar, hukum-hukum, prinsip-prinsip dan generalisasi, sehingga lebih memberikan kesempatan bagi berkembangnya keterampilan berpikir tingkat tinggi (Houston, 1988). Dengan demikian siswa lebih diberdayakan sebagai subjek belajar yang harus berperan aktif dalam memburu informasi dari berbagai sumber belajar, dan guru lebih berperan sebagai organisator dan fasilitator pembelajaran.

$$
\text { Pendekatan }
$$

saintifik

merupakan pendekatan yang mengadopsi langkah-langkah saintis dalam membangun pengetahuan melalui metode ilmiah. Untuk mengembangkan langkah-langkah saintis dalam membangun pengetahuan, pendekatan pembelajaran yang diperlukan adalah yang memungkinkan terbudayakannya kecakapan berpikir sains, terkembangkannya "sense of inquiry" dan kemampuan berpikir kreatif siswa (De Vito, 1989). Selain itu juga dibutuhkan pendekatan pembelajaran yang mampu menghasilkan kemampuan untuk belajar (Joyce and Weil: 2009), bukan saja diperolehnya sejumlah pengetahuan, keterampilan, dan sikap, tetapi yang lebih penting adalah bagaimana pengetahuan, keterampilan, dan sikap itu diperoleh siswa (Zamroni, 2000).

Mengacu pada teori-teori di atas dan dikaitkan dengan pendapat guru mengenai implementasi pendekatan saintifik dalam proses pembelajaran, dapat diambil kesimpulan sementara bahwa guruguru di SDN Kota Langsa sudah memahami pendekatan saintifik dan implementasinya dalam proses pembelajaran. Pendekatan saintifik menurut guru bercirikan penonjolan dimensi pengamatan, penalaran, penemuan, dan penjelasan tentang suatu temuan. Dengan demikian, dapat diterjemahkan bahwa implementasi pendekatan saintifik dalam proses pembelajaran berarti mengembangkan langkah-langkah saintis pada proses pembelajaran yang pelaksanaan pembelajarannya dipandu dengan nilai-nilai, prinsipprinsip, atau kriteria ilmiah untuk membangun siswa.

Kegiatan pendahuluan meliputi: apersepsi dan motivasi serta penyampaian kompetensi dan rencana kegiatan. Pada kegiatan 
pendahuluan ini yang tidak tampak selama peneliti melakukan observasi adalah guru menyampaikan garis besar cakupan materi dan penjelasan tentang kegiatan yang akan dilakukan siswa, serta kompetensi yang akan dicapai siswa di akhir pembelajaran. Sementara untuk aspek apersepsi, motivasi, dan persiapan siswa secara psikis dan fisik untuk mengikuti proses pembelajaran semua guru hampir melaksanakannya secara maksimal.

Untuk kegiatan inti, yang berkaitan langsung dengan implementasi pendekatan saintifik pada proses pembelajaran mulai dari langkah mengamati sampai mengkomunikasikan, tidak semua langkah tersebut dilaksanakan guru secara berurutan. Dan dari langkahlangkah 5M tersebut semuanya merupakan proses pembelajaran yang saling berkaitan satu sama lain antar substansi materi. Selanjutnya, berdasarkan pengamatan ditemukan bahwa ada langkah pendekatan saintifik yang tidak terlaksana secara maksimal oleh beberapa orang guru, yaitu langkah menanya dan mengasosiasi.

Kegiatan inti, merupakan kegiatan utama dalam proses pembelajaran atau dalam proses penguasaan pengalaman belajar (learning experience) siswa. Kegiatan inti dalam pembelajaran adalah suatu proses pembentukan pengalaman dan kemampuan siswa secara terprogram yang dilaksanakan dalam durasi waktu tertentu.
Pada kegiatan penutup hal yang kurang terlaksana dengan baik adalah melakukan penilaian dan/ atau refleksi terhadap kegiatan yang sudah dilaksanakan, memberikan umpan balik terhadap proses pembelajaran, dan merencanakan kegiatan tindak lanjut dalam bentuk program pengayaan. Penilaian yang dilakukan guru masih terpisah dengan proses pembelajaran yang dilaksanakan. Sementara itu untuk kegiatan membuat rangkuman/ simpulan pelajaran ada satu orang guru yang masih menyampaikan dengan ceramah dengan sedikit melibatkan siswa.

Menurut Sanjaya (2007: 373), "menyimpulkan adalah tahapan untuk memahami inti (core) dari materi pelajaran yang telah disajikan". Langkah menyimpulkan merupakan langkah yang sangat penting dalam pendekatan saintifik, sebab melalui langkah menyimpulkan siswa akan dapat mengambil intisari dari proses penyajian. Menyimpulkan berarti pula memberikan keyakinan kepada siswa tentang kebenaran suatu paparan. Dengan demikian siswa tidak merasa ragu lagi akan penjelasan guru. Sementara itu menurut Lazim (2013: 9), kegiatan penutup ditujukan untuk dua hal pokok. Pertama, validasi terhadap konsep, hukum atau prinsip yang telah dikonstruk oleh siswa. Kedua, pengayaan materi pelajaran yang dikuasai siswa.

\section{SIMPULAN}

Merujuk pada temuan penelitian dan pembahasan hasil penelitian yang telah diuraikan, maka secara umum dapat disimpulkan bahwa implementasi pendekatan saintifik

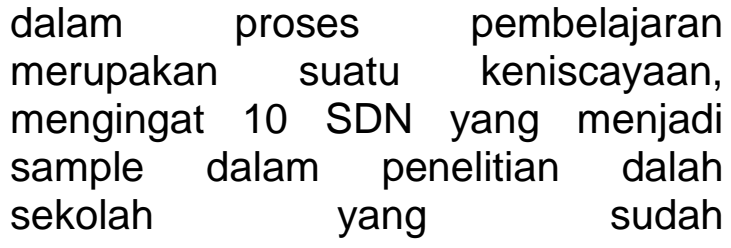


mengimpelementasi Kurikulum 2013. Proses pembelajaran dengan menggunakan pendekatan saintifik di dua sekolah ini dapat mendorong suasana kelas yang lebih aktif, menyenangkan, dan memicu antusiasme siswa. Suasana seperti inilah yang memberikan dampak terhadap pembelajaran yang menumbuhkan sikap kritis, bertanggungjawab, dan menumbuhkembangkan perilaku yang saling menghormati (respect) dari setiap siswa
Guru-guru di SDN se- Kota Langsa sudah menunjukkan pemahaman yang baik tentang pendekatan saintifik dan implementasinya dalam proses pembelajaran. Pada intinya pendekatan saintifik diterjemahkan guru sebagai sebuah proses pembelajaran yang secara keseluruhan bersifat ilmiah, dimana siswa pada pendekatan saintifik diarahkan untuk berpikir logis, sistematis dalam mencari kesimpulan terhadap materi pembelajaran.

\section{DAFTAR PUSTAKA}

Ango, M.L. (2002). "Mastery of Science Process Skills and Their Effective Use in the Teaching of Science: An Educology of Science Education in the Nigerian Context". International Journal of Educolog. Vol 16, (1), 11-30.

Aswandi. (2009). Pembelajaran Menyenangkan (online), (//http

www.pontianakpost.com/?mib= berita. detail\&id=22350. Diakses tanggal 16 Februari 2016)

Kemendikbud. (2013). Konsep Pendekatan Saintifik (ppt). Disajikan dalam Pelatihan Kurikulum 2013.

McColum. (2009). A Scientific Approach to Teaching [Online]. Tersedia:

http:/kamccollum.wordpress.com /2009/08/01/a-scientificapproach-to-teaching/ [diakses 25 Mei 2014]

Peraturan Menteri Pendidikan dan Kebudayaan Nomor 81A Tahun 2013 tentang Implementasi
Kurikulum.

Jakarta: Kemendikbud

Rustaman, N. (2007). Pendidikan dan Penelitian Sains dalam Mengembangkan Keterampilan Berpikir Tingkat Tinggi untuk Pembangunan Karakter. Bandung: FPMIPA UPI. (2005). Strategi Belajar Mengajar Biologi. Bandung: Universitas Pendidikan Indonesia.

(2003). Kemampuan Proses Ilmiah dalam Pembelajaran Sains. Bandung: Universitas Pendidikan Indonesia.

Sudrajat, A. (2013). Pendekatan Saintifik dalam Proses Pembelajaran. www.akhmadsudrajat.wordpress. com. Diunduh pada maret 2016.

Sugiyono. (2012). Memahami Penelitian Kualitatif. Bandung: Alfabeta.

Sugiyono. (2014). Metode Penelitian Pendidikan Pendekatan Kuantitatif, Kualitatif, dan $R \& D$. Bandung: Alfabeta

Wartono. (2006). Pengembangan Model Pembelajaran Inkuiri 
R. Fransyaigu, B. Mulyahati /DWIJA CENDEKIA: Jurnal Riset Pedagogik 2 (1) (2018) 52-60

Akrab Lingkungan Untuk
Mengembangkan Keterampilan
Berfikir dan Meningkatkan
Prestasi Belajar Siswa Dalam
Bidang Sains di Sekolah Dasar
(online). Desertasi.
Universitas Pendidikan
Indonesia. Bandung.
(http://didilib.upi.edu/pasca/ava
$\underline{\text { ilable/e td-1205105-104033, }}$
diakses maret 2016

Yunita. (2009). Hubungan Antara Karakteristik Responden,

Kebiasaan Makan dan Minum

Serta Pemakaian NSAID dengan
Terjadinya Gastritis pada Mahasiswa Kedokteran. [Online].

Tersedia:

http://adln.lib.unair.ac.id/.

[Diakses 25 Mei 2015].

Zubaidah, S. (2010). Berpikir Kritis: Kemampuan Berpikir Tingkat Tinggi yang Dapat Dikembangkan melalui Pembelajaran Sains. Makalah Seminar Nasional Sains. Universitas Negeri Surabaya. Surabaya 16 Januari 2010 